\title{
Social implications of rheumatic diseases
}

\author{
Anna Kłak ${ }^{1}$, Filip Raciborski ${ }^{1}$, Piotr Samel-Kowalik ${ }^{2}$ \\ ${ }^{1}$ Department of Gerontology and Public Health, National Institute of Geriatrics, Rheumatology and Rehabilitation, Warsaw, Poland \\ ${ }^{2}$ Department of Prevention of Environmental Hazards and Allergology, Medical University of Warsaw, Warsaw, Poland
}

\begin{abstract}
Social consequences of a disease constitute limitations in performing roles relating to working life as well as family and social life caused by the disease, mainly chronic. The aim of the study was to analyze the social consequences of rheumatic diseases in the aspect of disability pensions with respect to incapacity for work and quality of life. The occurrence of rheumatic diseases is related not only to increased risk of different types of organic changes, but above all disability. In Europe almost $50 \%$ of persons suffering from diseases of the musculoskeletal system who are currently unemployed were breadwinners. Nearly $60 \%$ of them received legal disability status. The loss of work ability is, among other things, the consequence of progressive disability. In Europe 40\% of persons suffering from rheumatoid arthritis (RA) had to stop working due to the disease. Most of the persons diagnosed with RA were of working age. It results in the decrease in the quality of life as well as economic difficulties (decreased incomes and increased disease-related costs). In Poland the results of the analysis of the Social Insurance Institution (ZUS) of first-time disability recognition issued for the purpose of disability pensions in 2014 showed that the incapacity for work was caused by diseases relating to general health condition (65.5\%). Diseases of the musculoskeletal system were the cause of partial inability to work of $21.6 \%$ of persons who received a disability pension for the first time (as many as 5,349 certificates were issued). Early diagnosis and implementation of effective treatment are the necessary conditions for a patient to sustain activity, both professional and social, which is of crucial importance to reduce the negative effects of the disease.
\end{abstract}

Key words: rheumatic diseases, social effects, disability pensions.

\section{Introduction}

Rheumatic diseases are chronic and progressive. They cause damage to the locomotor system and lead to patient disability [1]. These diseases significantly reduce the quality of life of the patient $[1,2]$. Rheumatic complaints of the locomotor system are common and affect around 30-40\% of the European population [3]. Estimates indicate that in Poland up to 400000 persons were treated at hospitals in 2014 due to both inflammatory and non-inflammatory diseases of the joints included in the International Statistical Classification of Diseases and Related Health Problems (ICD-10) from the code M00 to M99 [4]. The most frequently occurring inflammatory rheumatic diseases include rheumatoid arthritis and spondyloarthropathies. Connective tissue diseases, such as Sjögren's syndrome, systemic lupus erythematosus, scleroderma or dermatomyositis, occur less often [5-8].

Social and health outcomes of a disease are the limitations in performing roles relating to working life, family and social life. They are caused by the disease - mainly chronic. The type of limitations may be temporary or permanent. Disability as a result of the chronic process of the disease or injury is a particular type of social effects. Social implications of the disease can be analysed in the following terms:

\section{Address for correspondence:}

Anna Kłak, Department of Gerontology and Public Health, National Institute of Geriatrics, Rheumatology and Rehabilitation, Spartańska 1, 02-637 Warsaw, Poland, e-mail: anna.klak.@spartanska.pl.

Submitted: 15.04.2016; Accepted: 28.04.2016 
- physical and biological - as limitations in performing regular life functions,

- professional - meaning limitations in the ability to work or complete incapacity for work,

- legal - acquisition of entitlement to benefits defined in relevant legal acts, e.g. disability pensions, sickness benefits [9].

In the case of rheumatic diseases, multiple organ failures, which often lead to death, are a major consequence. The inability to function on a labour market (the loss of work ability) is also a common implication [10]. In many cases patients suffering from rheumatoid arthritis (RA), ankylosing spondylitis (AS) or psoriatic arthritis have to stop working and rely on a disability pension. This situation constitutes a risk of impoverishment of these patients. According to the data of the Central Statistical Office of Poland (GUS), the risk of extreme poverty rate in the group of pensioners was $12.5 \%$ in 2014 , whereas it was significantly lower in the general population and was $7.4 \%$ [11].

It is worth underlining that inflammatory rheumatic diseases also relate to children [12]. Chronic disease of a child significantly influences the life of parents, in particular the financial situation of their household. The results of the study carried out in Germany by Minden's team in a group of 369 children suffering from juvenile idiopathic arthritis (JIA) showed that the average total cost of JIA was estimated at EUR 4663 per patient per year. The highest costs were estimated for patients with seropositive polyarthritis and systemic arthritis (EUR 7876), whereas the lowest costs were estimated for patients with persistent oligo-arthritis (EUR 2904). The costs of healthcare constituted $89 \%$ of the total costs and the costs of drugs constituted nearly half of the value. A substantial part of the costs was borne by the child's family, with a mean out-of-pocket cost of $223 \mathrm{eu}$ ros and a mean indirect cost due to time lost from work of 270 euros per year per family. The increase in costs corresponded to the increase in: disease activity and pain, duration of the disease, time between the occurrence of symptoms and first visit to the rheumatologist. The authors of the study concluded that JIA constitutes a substantial economic burden, especially if the child is treated with biopharmaceuticals that contribute to the increase in total cost of the disease [13].

\section{Disability}

There are different definitions of a disabled person. The World Health Organisation defines three terms of disability: injury (impairment), functional disability (disability) and impairment or social disability (handicap). The first term means any deficiency or abnormal anato- my of organ structure as well as a deficiency or mental or physiological disorder of the body due to a defined congenital disorder, a disease or an injury. Functional disability means any restriction or deficiency, which results from impaired ability to perform an activity in the defined manner. Impairment or social disability means a less privileged or less favourable situation of a given individual, resulting from an injury or functional disability. This type of disability limits the fulfilment of a role relating to age, sex and social and cultural factors [14].

Disabled people in general can be divided into two basic groups: legally and biologically disabled. Legal disability is confirmed by a decision establishing disability or a degree of disability, issued by an authority empowered for that purpose. Biological disability is a subjective feeling of limitations in fulfilment of basic activities for a given age, without a disability certificate. The Central Statistical Office (GUS) defines a legally disabled person as having a valid certificate of disability issued by an authority empowered for that purpose [15]. The results of the National Population and Housing Census carried out in Poland in 2011 show that the number of persons who declared limitations in ability to perform regular basic activities for a given age and/or had a valid certificate of disability was 4697500 , which constituted $12.2 \%$ of the population. Among people with disabilities there were 2530400 women. The group of men with disabilities in 2011 numbered 2167100 persons [15]. According to GUS data in $23.4 \%$ of households there is at least one person who holds a certificate of disability issued by the Disability Assessment Board. In 2013 in Poland disability was mostly reported in households entitled to receive a disability pension (people with disabilities occurred in $61.4 \%$ of this group of households). In the group of retirees' households this percentage was $25.4 \%$. As many as $10.8 \%$ of respondents at the age of 16 years or more had a certificate of disability (3\% severe, $5 \%$ moderate, $2.8 \%$ mild). Over $86 \%$ of people with severe disability were under constant medical or nursing supervision [16].

In the ranking of the 10 leading causes of health loss in Central Europe, musculoskeletal disorders were ranked as fifth (after lower back pain, major depression, falls and neck pain) [17]. It should be however noted that lower back pain and neck pain are also symptoms of some musculoskeletal disorders. Rheumatic diseases influence not only the ability to work, but also everyday functioning of a patient and his or her independence. The most common problems of everyday life reported by patients suffering from rheumatic diseases include getting dressed, getting up, turning the tap on, opening the cap of a bottle, getting on the bus and not having a free seat, inability to walk the stairs and open heavy doors, and inability to stand for a long period of time [18]. The 
problems with performing simple activities of everyday life have a significant impact on the loss of independence, hamper social relations and may even constitute a risk of poverty. The authors of the "Fit for Work" study state that in Europe almost $50 \%$ of persons suffering from a disease of the musculoskeletal system, who are currently unemployed, were breadwinners. Nearly 60\% of them received legal disability status [19].

The results of a study carried out in the years 2009 2010 in Poland, which included 1000 respondents suffering from RA (average age of 60 years) who were the patients of 50 rheumatology out-patient clinics selected at random, showed that $53 \%$ of RA patients received legal disability status. Among them 35\% (19\% of all respondents) are considered to be severely disabled while $64 \%$ (33\% of all respondents) have a moderate degree of disability [20]. As many as $41 \%$ of respondents stated that they needed to adapt their living conditions to the limitations resulting from the disease, and only $5 \%$ out of 1000 respondents stated that they had already adjusted their environment. The most frequent adaptations include appropriate bathroom equipment (6\%) and purchase of a dishwasher (5\%) [20].

Rheumatic diseases can cause pain and fatigue that reduce work efficiency, which many employees do not want to reveal. Inflammatory diseases of the joints can also influence work safety, e.g. when a disease or associated pain affects the concentration or movement of a worker. The authors of the "Fit for Work" report indicate that $30 \%$ of Polish employees who suffer from rheumatoid arthritis are reluctant to disclose their condition to co-workers and superiors because they fear discrimination and $22 \%$ of employees do not inform the employers about their health issues [21].

Rheumatic diseases can hamper everyday activities, which forces many patients to leave work. It is estimated that in Europe $40 \%$ of RA patients had to stop working due to the disease. It should be kept in mind that most persons were of working age when diagnosed with RA [22]. In Europe the percentage of sickness absence due to musculoskeletal disorders (MSD) constitutes nearly half of all absences due to disease or health condition [19]. In the case of patients suffering from ankylosing spondylitis the percentage of unemployed is three times higher than in the general population [22]. As indicated by the World Bank data for Poland, disability is the main reason for inactivity for men aged 45-59 and for women aged 45-54 [23].

The results of the study carried out in Poland by Tasiemski's team (2009) indicate that almost $62 \%$ of RA patients were employed before the occurrence of disease symptoms. After the diagnosis $45 \%$ of patients had to stop working. Nearly half of the RA patients in the study had to rely on disability pension and were at high risk of poverty [24]. Experts suggest that after five years from the onset of the disease only half of RA patients are working. After ten years from the onset the number of those remaining in employment decreases to 20\% [21]. As many as $32 \%$ to $50 \%$ of patients stop working within 10 years from the onset of rheumatoid arthritis. At least $12.1 \%$ of all sickness absence results from rheumatic diseases. It is estimated that in the UK almost a quarter of RA patients quit work within five years from the diagnosis of the disease. This figure can increase to $40 \%$ if the effects of co-existing conditions such as depression and cardiac and respiratory complaints are taken into account [25].

\section{Disability pensions due to musculoskeletal disorders}

The Social Insurance Institution (Zakład Ubezpieczeń Spotecznych - ZUS) does not publish the information on the number of pensioners based on disease entities, which makes it impossible to carry out in-depth analysis. Detailed data broken down by ICD10 codes for diseases are available only for primary decisions.

In 2014 ZUS issued a total of 6069 primary decisions for disability pensions due to diseases of the musculoskeletal system and connective tissue, out of which $88.1 \%$ were partial incapacity for work, $11.4 \%$ were total incapacity for work and $0.4 \%$ were inability to lead an independent life. ZUS data show an upward trend in the number of primary decisions issued for the purpose of disability pensions due to musculoskeletal and connective tissue disorders in the years 2012-2014 (Table I). In 2014 also 33722 renewed decisions were issued, out of which $84.6 \%$ were partial incapacity for work, $12.6 \%$ were total incapacity for work and $2.7 \%$ were inability to lead an independent life [26].

According to ZUS data of 2014 the percentage of primary decisions issued for the purpose of disability pensions by medical commissions that established a degree of work incapacity due to diseases of the musculoskeletal system was $15.7 \%$ of the total primary decisions in the group of women and $12.6 \%$ in the group of men [26].

The results of analysis of ZUS data on primary decisions issued for the purpose of disability pensions in 2014 indicate that most frequently the incapacity for work was caused by diseases related to the general state of health. The diseases were as follows: neoplasms constituted $23.5 \%$ of the total decisions, diseases of the circulatory system $-20.4 \%$, and diseases of the musculoskeletal system that were the cause of partial incapacity for work in the case of $21.6 \%$ of individuals who received disability pension for the first time. In 2014 the 
Table I. Primary decisions of ZUS physicians issued in the years 2012-2014 by gender*

\begin{tabular}{|llllllcccccc|}
\hline \multirow{2}{*}{$\begin{array}{l}\text { ICD10 } \\
\text { code }\end{array}$} & Disease entity & \multicolumn{3}{c}{ Year 2012 } & \multicolumn{3}{c|}{ Year 2013 } & \multicolumn{3}{c|}{ Year 2014 } \\
\cline { 2 - 11 } & Total & Men & Women & Total & Men & Women & Total & Men & Women \\
\hline M00- & $\begin{array}{l}\text { Diseases of the musculoskeletal } \\
\text { system and connective tissue }\end{array}$ & 5440 & 3102 & 2332 & 5914 & 3424 & 2488 & 6069 & 3616 & 2445 \\
\hline M05 & Seropositive rheumatoid arthritis & 344 & 118 & 226 & 380 & 116 & 264 & 339 & 119 & 219 \\
\hline M06 & Other rheumatoid arthritis & 113 & 42 & 71 & 139 & 49 & 90 & 125 & 46 & 79 \\
\hline M10 & Gout & 25 & 24 & 1 & 23 & 23 & 0 & 29 & 27 & 2 \\
\hline M32 & Systemic lupus erythematosus & 76 & 9 & 67 & 69 & 15 & 54 & 54 & 11 & 43 \\
\hline M45 & Ankylosing spondylitis & 84 & 69 & 15 & 73 & 63 & 10 & 109 & 94 & 15 \\
\hline
\end{tabular}

*In the case of gender ZUS distinguishes the category "undefined gender" that was not taken into account in the presented table. In 2013 there were 2 primary decisions in this category classified in the group M00-M99, in 2012-2016, and in 2014-2018.

Source: Own work based on ZUS data [26].

percentage of primary decisions issued for the purpose of disability pensions by ZUS physicians who established a degree of incapacity for work due to diseases of the musculoskeletal system was $12.6 \%$ for men and $15.6 \%$ for women [26].

\section{Quality of life}

Rheumatic diseases, both inflammatory and non-inflammatory, significantly affect the reduction of quality of life in terms of functioning within society and mood [27-29]. The results of a meta-analysis carried out by Bujkiewicz's team (2014) confirm the increase of the $\mathrm{HAQ}^{1}$ (Health Assessment Questionnaire) indicator together with the disease duration as well as DAS28 (Disease Activity Score) among patients diagnosed with rheumatoid arthritis [30]. The study showed that RA activity significantly affects the level of pain perceived by the patient. The increase of pain assessment in the DAS28 algorithm by $12.5 \pm 1.2$ points was observed along with the progress of the disease [31].

The results of a study carried out in Poland (Prais, 2007) indicate that the quality of life of patients with rheumatoid arthritis depend on the radiological and functional stage of the disease, and its duration. Quality of life of RA patients was evaluated with the following questionnaires: Medical Outcomes Study 36 - SF-36, Health Assessment Questionnaire - HAQ and Arthritis Impact Measurement Scale - AIMS. No significant correlations were found between the duration of the disease, the age of patients and the activity of the disease. Patients whose disease lasted longer and in whom the inflammatory processes were more active assessed their quality of life as poorer. It was found that radiologi- cal and functional stage of disease significantly affected the assessment of quality of life in the examined group. No significant differences in the evaluation of quality of life between men and women were found [32].

The results of studies carried out in Spain and Australia indicate that the quality of life of women suffering from RA is often low [31,33]. The results of Spanish studies did not show a relation between the level of education of patients and their quality of life [31]. The HAQ score of women with RA is 1.4 and that of men with RA is 0.9 [33]. Women suffering from RA more often than men need the assistance of relatives or friends (women: $65 \%$, men: $25 \%)$. The support is needed in the following situations: domestic responsibilities (70\%), shopping (41\%), handling of heavy objects (20\%), transport (15\%), opening jars (15\%), and personal hygiene (11\%) [33]. It should be noted that pain and reduced mobility that hamper everyday activities occur also in the case of osteoarthritis [34].

Patients with rheumatoid arthritis are often financially dependent on other persons (family, friends). Young persons more often speak about the negative influence of the disease (RA) on their functioning within society than persons aged 65 and more. According to young people, RA negatively affects their social life and outdoor sports activities [33]. The results of Norwegian studies show that health-related quality of life (HRQoL) is significantly lower in the group of RA patients than in the general population. It affects all age groups - both women and men (with regard to the health aspect as well as social functioning, physical condition, mental health, and emotional capacities) [35]. Kanecki's team (2013), which carried out a study on the assessment of health-related quality of life ( $\mathrm{HRQOL}$ ) in a group of patients hospitalised due to RA ex-

${ }^{1}$ The minimum value of the indicator is 0 and the maximum is 3. A higher value means greater disability. 
acerbation ( $n=58$, mean age of 62.5 years), presented slightly different results. A planned 2-year observation of patients in an outpatient setting (mean duration of the study was 22-23 months) was carried out. The HRQoL analysis was performed using the SF-36 questionnaire. Statistically significant reductions in HRQoL scores were observed in social functioning $(p<0.05)$, whereas emotional health $(p<0.05)$ and mental health $(p<0.05)$ scores were increased [36].

The study carried out in Poland by Tasiemski's team showed that only $38 \%$ of individuals with RA were satisfied with their life, with the disease having the greatest impact on professional issues and the financial situation [24]. The results of the Polish-German study carried out by Bugajska's team (2010) showed that $95 \%$ of Polish patients with RA $(n=300)$ felt excluded from social life, compared to $62 \%$ of German patients $(n=137)$ [37]. The authors of the "Fit for Work" report found that rheumatic diseases limit the possibilities of education and decrease the chances for promotion even among persons who are professionally active [21].

\section{Summary}

Rheumatic diseases, especially inflammatory diseases, should not be viewed exclusively in the framework of health implications. The development of the disease is associated not only with increased risk of organ failure, but above all with progressive disability and increasing mental problems. This translates into reduced quality of life as well as financial difficulties (decreased income and increased disease-related costs). Early diagnosis and implementation of effective treatment are the necessary conditions for a patient to sustain activity, both professional and social, which is of crucial importance to decrease negative outcomes of the disease. Staying in the labour market is also favourable from the perspective of the social aspect and the health insurance system.

The authors declare no conflict of interest.

\section{References}

1. Anyfanti P, Triantafyllou A, Panagopoulos P, et al. Predictors of impaired quality of life in patients with rheumatic diseases. Clin Rheumatol 2015 Dec 23. [Epub ahead of print].

2. Branco JC, Rodrigues AM, Gouveia N, et al. Prevalence of rheumatic and musculoskeletal diseases and their impact on health-related quality of life, physical function and mental health in Portugal: results from EpiReumaPt - a national health survey. RMD Open 2016; 2: e000166.

3. Oświadczenie Parlamentu Europejskiego w sprawie chorób reumatycznych, 2009/C $285 \mathrm{E} / 11$.
4. Narodowy Instytut Zdrowia Publicznego - Państwowy Zakład Higieny. Tabele wynikowe Badania Chorobowości Szpitalnej Ogólnej. http://www.statystyka.medstat.waw.pl/wyniki/TabelaEurostat2014szac.htm [Access: 15.01.2016].

5. Scott DL, Wolfe F, Huizinga TW. Rheumatoid arthritis. Lancet 2010; 376: 1094-1108.

6. Dean LE, Jones GT, Macdonald AG, et al. Global prevalence of ankylosing spondylitis. Rheumatology (Oxford) 2014; 53: 650657.

7. Baillet A, Gossec L, Carmona L, et al. Points to consider for reporting, screening for and preventing selected comorbidities in chronic inflammatory rheumatic diseases in daily practice: a EULAR initiative. Ann Rheum Dis 2016; 75: 965-973

8. Gryglewicz J, Kosowicz M, Olesińska M, et al. Toczeń rumieniowaty układowy w Polsce. Ogólnopolskie Stowarzyszenie Młodych z Zapalnymi Chorobami Tkanki Łącznej „3majmy się razem", Warszawa 2012.

9. Tobiasz-Adamczyk B. Wybrane elementy socjologii zdrowia i choroby. Wydawnictwo Uniwersytetu Jagiellońskiego, Kraków 2000.

10. Listing J, Kekow J, Manger B, et al. Mortality in rheumatoid arthritis: the impact of disease activity, treatment with glucocorticoids, TNF inhibitors and rituximab. Ann Rheum Dis 2015; 74: 415-421.

11. Ubóstwo ekonomiczne w Polsce w 2014 r. Główny Urząd Statystyczny, Warszawa: 2015. stat.gov.pl/download/gfx/portalinformacyjny/pl/.../ubostwo_2014.pdf [Access: 5.04.2016].

12. Tłustochowicz M, Śliwczyński A, Iltchev P, et al. Juvenile idiopathic arthritis morbidity rate in rural and urban areas of Poland 2008-2012. Ann Agric Environ Med 2015; 22: ICID: 1185780.

13. Minden K, Niewerth $M$, Listing J. The economic burden of juvenile idiopathic arthritis-results from the German paediatric rheumatologic database. Clin Exp Rheumatol 2009; 27: 863869.

14. World Health Organization http://www.who.int/en/ [Access: 7.04.2016].

15. Główny Urząd Statystyczny. Raport z wyników. Narodowy Spis Powszechny Ludności i Mieszkań 2011. Warszawa 2012.

16. Ochrona zdrowia w gospodarstwach domowych w 2013 roku. Główny Urząd Statystyczny. Warszawa 2014.

17. Murray CJ, Vos T, Lozano R, et al. Disability-adjusted life years (DALYs) for 291 diseases and injuries in 21 regions, 1990-2010: a systematic analysis for the Global Burden of Disease Study 2010. Lancet 2012; 380: 2197-223.

18. Grygielska J. Ocena wybranych dziedzin życia w chorobach reumatycznych - analiza porównawcza badań ankietowych. Reumatologia 2008; 46: 230-234.

19. Fit for Work Europe Patient Survey report. October 2012.

20. Grygielska J. The impact of rheumatoid arthritis on the economic situation of Polish households. Reumatologia 2013; 51: 348-354.

21. Zheltoukhova K, Bevan S, Reich A. Zdolni do pracy? Choroby układu mięśniowo-szkieletowego a rynek pracy w Polsce. Fit for Work Europe, 2011.

22. Musculoskeletal Disorders and the European Workforce: The Facts. Fit for Work Europe, 2012.

23. Bank Światowy. Europe 2020 Poland. Fueling Growth and Competitiveness in Poland Through Employment, Skills, and 
Innovation. Overview. World Bank Human Development and Private and Financial Sector Development Departments, Washington 2011.

24. Tasiemski T, Angiaszwili-Biedna N, Wilski M. Assessment of objective and subjective quality of life in people with rheumatoid arthritis - Preliminary study. Ortopedia, Traumatologia, Rehabilitacja 2009; 4: 346-359.

25. Bevan S, Passmore E, Mahdon M. Fit For Work? Musculoskeletal Disorders and Labour Market Participation. The Work Foundation, UK 2007.

26. Łabęcka M, Kania A. Orzeczenia lekarzy orzeczników ZUS o niezdolności do pracy wydane w 2014 roku. Zakład Ubezpieczeń Społecznych, Warszawa 2015.

27. Carr AJ. Beyond disability: measuring the social and persona consequences of osteoarthritis. Osteoarthritis and Cartilage 1999; 7: 230-238

28. da Mota LMH, dos Santos Neto LL, Burlingame RW, et al. Disability and quality-of-life are not influenced by the prevalence of autoantibodies in early rheumatoid arthritis patients - results of the Brasília Cohort. Rev Bras Reumatol 2012; 52: 819 829.

29. Boyd TA, Bonner A, Thorne C, et al. The Relationship Between Function and Disease Activity as Measured by the HAQ and DAS28 Varies Over Time and by Rheumatoid Factor Status in Early Inflammatory Arthritis (EIA). Results from the CATCH Cohort. Open Rheumatol J 2013; 7: 58-63.

30. Bujkiewicz S, Thompson JR, Sutton AJ. Use of Bayesian Multivariate Meta-Analysis to Estimate the HAQ for Mapping Onto the EQ-5D Questionnaire in Rheumatoid Arthritis. Value Health 2014; 7: 109-115.

31. Silva Luna K, Ortiz AM, Patiño E, et al. Influence of the structure of mood in the assessment of rheumatoid arthritis through the visual analog scale for pain, HAQ and DAS28. Reumatol Clin 2012; 8: 328-333.

32. Prais K. Jakość życia chorych na reumatoidalne zapalenie stawów w odniesieniu do sprawności fizycznej i stanu psychicznego. Ann Acad Med Stetenensis 2007; 53: 72-82.

33. Lapsley HM, March LM, Tribe KL, et al. Living with rheumatoid arthritis: expenditures, health status, and social impact on patients. Ann Rheum Dis 2002; 61: 818-821.

34. Brooks PM. Impact of osteoarthritis on individuals and society: how much disability? Social consequences and health economic implications. Curr Opin Rheumatol 2002; 14: 573 577.

35. Uhlig T, Loge JH, Kristiansen IS, et al. Quantification of reduced health-related quality of life in patients with rheumatoid arthritis compared to the general population. J Rheumatol 2007; 34: 1241-1247.

36. Kanecki K, Tyszko P, Wisłowska M, et al. Preliminary report on a study of health-related quality of life in patients with rheumatoid arthritis. Rheumatol Int 2013; 33: 429-434.

37. Bugajska J, Brzosko M, Jędryka-Góral A, et al. Psychological stress in rheumatoid arthritis patients: a comparative PolishGerman study. Autoimmun Rev 2010; 9: 211-215. 